\title{
Production, Marketing and Value Chain Analysis of Guava in Allahabad District of Uttar Pradesh, India
}

\author{
Preksha Manna, Atul Anand Mishra, R.N. Shukla \\ Department of Food Process Engineering, SHIATS, Allahabad
}

\begin{abstract}
Allahabad region is best known for the guava. The study aims to observe the total production of guava under different size holding for that the farmers were divided into three size groups small, medium and large. The average total yield in different size groups was calculated. It was found that there were two main channels prevailing in the District. There were lots of problems involved in the VCA of guava viz. absence of producer's association, guava wilt, long chain of middlemen and absence of VCA intelligence and finance.
\end{abstract}

Keywords-Value Chain Analysis (VCA), marketing, producer.

\section{INTRODUCTION}

Guava (psidium guajava L) is one of the most important fruit of India, it is considered to be poor man's apple. The guava tree (psidium guajava L) is a native of Tropical America, but now it is found in all parts of the tropics. . Guava is cultivated in 148200 hectares (ha), with a production of 163 million tons all over the country.Fruits and vegetables are perishable in nature and cannot be stored for longer periods, which result in very sensitive and complicated trading of these horticultural commodities and exposing big challenges to suppliers, processors and traders. In addition, the inconsistent availability of healthy fruits and vegetabes from farm-gate to the consumers, continuous quality assurance push by the traders and supermarkets, competitive global environment, increasing trend of better supply by companies of other competitive countries and also more and more implications of quality standards are also parallel competitive elements making this business more vulnerable and complex. Therefore, to cope with these challenges, the only integrated way to be applied from farm gate collection through washing, grading, packaging, storage and VCA to ultimate consumer is to establish the consistent and sustainable supply of "Farm-to-fork Approach", currently transformed as Value
Chain Analysis (VCA) or Supply Chain Management (Mishra et al. 2013) .

Value Chain Analysis (VCA) is the oversight of materials, information and finances as they move in a process from supplier to manufacturer to wholesaler to retailer to consumer. Value Chain Analysis involves coordinating and integrating these flows both within and among companies. Value Chain Analysis has become one of the most popular and fastest growing areas in management. "A supply chain consists of all stages involved, directly or indirectly, in fulfilling a customer request. To remain competitive, small firms have to offer superior quality goods at the lowest prices possible. The need to minimize product costs makes effective Value Chain Analysis vital. There are costs involved in every process of the product life cycle, and it is the responsibility of management to ensure that these costs are kept low, so the company can continue to pass along these savings to the consumer. Value Chain Analysis involves identifying those processes that increase cost without increasing the value of the final product. Presently food markets are becoming globalised and trade more and more concentrated and internationalized, but at the same time, quality assurance and traceability requirements against suppliers have also increased significantly (Spriggs, 1999). Increased food safety requirements are now expected to exercise more strongly on fresh products (Unnevehr, 2000) due to the facts that food safety and quality components have an outstanding role with respect to fresh products supplied through VCA channels. Food safety and quality requirements have an increasing importance around the globe (Kalei, 2008). Dissemination and introduction of the quality assurance systems such as GLOBALGAP, International Food Standards (IFS). (Mishra et al. 2013) Involved in the VCA of guava. Hence the study was carried out with the following objectives, To study the marketing pattern and Value Chain Analysis of guava in Allahabad 
District of Uttar Pradesh, India and To study the problems involved in the Production and VCA of guava.

\section{MATERIALS AND METHODS}

VCA of guava in Allahabad district was aimed to make an appraisal about the Value Chain Analysis of guava in Allahabad district. The study were divided in several stages.

\section{Stage 1 Selection of district}

Allahabad district was selected, as it has a large area under guava production and is famous for the production of guava on commercial scale.

\section{Stage $2 \mathrm{~S}$ e $\mathrm{l}$ e c $\mathrm{t}$ i o $\mathrm{n}$ of VCA functionaries}

1. Selection of Wholesaler: 12 wholesalers were selected randomly for the study.

2. Selection of Retailer: 8 retailers were selected randomly for the study.

3. Selection of farmers: 100 farmers were selected out of which 23 from small scale, 14 from medium scale and 13 from large scale were selected.

Method of collection of data: Two types of data were collected.

Primary Data: Daraganj and Mundera mandi was selected purposively for the study of primary data. It is basically a primary market where guava is brought for sale from where it is dispatched to different parts of Allahabad district and also to the other states.

Analysis of data: Tabular method was used for the analysis of data.

Period of enquiry: The period of enquiry was related to the agricultural year 2013-2014

VCA Cost: It includes all the VCA charges from local assembling to retailing in the VCA process.

Producer's share in consumer's rupee: The producer receives what the consumer pay after the various cost of VCA has been deducted (Mishra et. al 2013).

It was calculated by,

$P=\frac{\mathrm{C}-\mathrm{M}}{\mathrm{C}} \neq 100$

Where,

$\mathrm{P}=$ Producer's share in consumer's rupee. $\mathrm{C}=$ Consumer's price.

$\mathrm{M}=\mathrm{VCA}$ cost

Market surplus: It is a theoretical concept of surplus. This may be expressed as follows

$\mathrm{MS}=\mathrm{P}-\mathrm{C}$

MS = market surplus. $\mathrm{P}=$ total production

www.ijeab.com
$\mathrm{C}=$ total requirement( family consumption, farm needs)

The prevalent Supply Chains / channel of guava: (Mishra et. al 2013).

1. Supply Chain - 1

Producer $\rightarrow$ wholesaler $\rightarrow$ Retailer $\rightarrow$ Consumer

2. Supply Chain - 2

Producer $\rightarrow$ Contractor/ commission agent $\rightarrow$ Wholesaler $\rightarrow$ Retailer $\rightarrow$ Consumer

In the context of modernizing socio-economic infrastructure of farming community, Value Chain Analysis of agriculture produce has a vital importance of making farm economy sound and in boosting up the productivity. VCA of agriculture commodities in general and fruit crops in particular play an important role in safeguarding the interest of producer as well as consumer.

Progress of agriculture requires organized system of VCA of the produce so as to make food available at reasonable prices to consumers as well as grant fair return to producers. And therefore such a chain comes into existence involving the role of different intermediataries or middlemen.

\section{Transportation}

2

(a)Bullock cart

(b)Rickshaw

(c) Tonga

(d) Taxi

(e) Mini trucks

(f) Trains

(h) Ship

\section{Grading:}

It may be defined as the sorting of unlike lots of produce into different lots.

Method of Analysis:

Simple statistical analysis and statistical tools were used for the estimation and interpretation of the VCA supply chain analysis. (Mishra et. al 2013).

Net Market price/ amount received by producer $=\mathrm{NMP}_{\mathrm{p}}$

Growing price of producer $=\mathrm{GPP}$ 
Total VCA charges paid by the producer for packaging, transportation, palledari etc $=\mathrm{TMCP}$

$$
\operatorname{NMP}_{\mathbf{p}}==\mathbf{G P P}-\mathbf{T C P}
$$

\section{Post Harvest Losses of Guava:}

The post harvest losses [PHL] of guava fruit were estimated under two heads viz; physical post harvest loss and Economic post harvest loss.

\section{PRODUCTION PROBLEMS}

1. Labor: About 73\%, $80 \%$ and $12 \%$ Guava producers, respectively reported labor shortage as a major constraint. Hiring labor is a common practice in the district.

2. Credit: Lack of horticultural production credit provider and unavailability of credit on demand was indicated as constraints by $64.8 \%, 18.2 \%$ and $18.2 \%$ guava respondents. (Mishra et. al 2013).

VCA/ Supply Chain Management Problem. (Mishra et. al 2013).

1. Unfair price quotation - In the study area repeated low pricing was reported at peak supply periods that were not based on the actual supply and demand interaction but information collusion created by buying actors.

2. Lack of strong cooperatives- Over their marketable produces, farmers were exposed to baseless traders, ultimately sell their produce at low price. On top of this, local traders and elite farmers went to weaken the limited activities under taken by cooperative.

\section{RESULTS AND DISCUSSIONS}

Study of the utilization pattern is essential in order to get the clear picture of VCA pattern of producer and also study the influence of these VCA factors on the VCA surplus. Channel wise disposal shows the degree of sophistication. Growers tend to sell their produce in the market through different channels. Sale to village is also enhanced due to indebtedness of the producer to the contractor. The contractors also act as money lenders.

The table 1 indicates the total production of guava under different size holdings There were total 100 farmers selected for the study out of which 46 were selected for small (having less than 1 hectare area) 28 for medium (having area around 1-2 hectares) and 26 for large size groups (having area more than 2 hectares). The total yield of guava was 57.88,102.4 and 194.83 in small medium and large size group. The sample average of the total yield was 118.37. The home consumption was $0.65,0.75$ and 0.86 in small, medium and large size group. The sample average of home consumption was 0.753 . The payment as wages was $0.69,0.79$ and 1.03 in small, medium and large size groups. The sample average of payment as wages is 0.836. The market surplus was 38.39, 96.24 and 197.2 in small, medium and large size groups. The sample average of market surplus is 110.61 .

Table.1: Total production of guava under different size holdings. $N=100(S=46, M=28, L=26)$

\begin{tabular}{|c|c|c|c|c|c|}
\hline \multirow{2}{*}{} & & \multicolumn{2}{|c|}{ Different size groups } & \multirow{2}{*}{ Sample } \\
\cline { 3 - 6 } S.No. & Particulars & Small & Medium & Large & $\begin{array}{c}\text { Saverage } \\
\text { and }\end{array}$ \\
\cline { 3 - 6 } & Total yield of guava (qtls) & 57.88 & 102.4 & 194.83 & 118.37 \\
\hline 1. & Home consumption (qtls) & 0.65 & 0.75 & 0.86 & 0.753 \\
\hline 2 & Payment as wages (qtls) & 0.69 & 0.79 & 1.03 & 0.836 \\
\hline 4 & Market surplus(qtls) & 38.39 & 96.24 & 197.2 & 110.61 \\
\hline
\end{tabular}

Different supply chains existing in Allahabad district have been studied and tabulated as under the table 2 indicates the average VCA cost and margin of guava.(channel1.) The VCA cost incurred by producer was found to be Rs 172.30/qt, wholesaler Rs. 112.76/qt and retailer www.ijeab.com
Rs98.70/qt. The sales price of producer was found to be Rs.440/qt, wholesaler Rs.640/qt and in case of retailer was Rs.880/qt. The purchase price of producer was nil, wholesaler Rs.440/qt and in case of retailer was Rs.640/qt. The net amount received was found to be Rs 278.70/qt

Page | 121 
in case of producer, Rs 92.24/qt in case of wholesaler and 117.30 in case of retailer.

Table.2: Average VCA cost and margin of guava in channel $1(R s / q t)$.

\begin{tabular}{|c|c|c|c|c|}
\hline Particulars & VCA Cost & Sale Price & $\begin{array}{c}\text { Purchase } \\
\text { Price }\end{array}$ & $\begin{array}{c}\text { Net } \\
\text { Price }\end{array}$ \\
\hline Producers & 172.30 & 440 & - & 267.70 \\
\hline Wholesaler & 112.76 & 640 & 440 & 87.24 \\
\hline Retailer & 98.70 & 880 & 640 & 141.30 \\
\hline
\end{tabular}

The table 3 indicates the average VCA cost and margin of guava. The VCA cost by pre-harvest contractor as Rs.283.42/qt, wholesaler as Rs.140.40/qt and retailer as Rs.117.85/qt. The sales price in case of producer was Rs. 409/qt, pre-harvest contractor Rs.735/qt, wholesaler Rs.1080/qt and by retailer Rs 1395/qt. The purchase price of pre-harvest contractor was Rs.409/qt, wholesaler Rs.735/qt and by retailer Rs.1080/qt. Therefore if we see the net price received by producer was Rs.409/qt, pre-harvest contractor was Rs.42.68/qt, wholesaler Rs.204.60/qt and in case of retailer was Rs.197.15/qt. Since the producer sells his produce directly to the pre-harvest contractor he does not pay any VCA charges and receives a net amount of Rs. 409/qt.In channel 2 the net amount received by the producer is more as compared to channel 1. But a large part of it is wasted in transportation and also in giving commission to the commission agent. (Mishra et. al. 2013). Table 3: The average VCA cost and margin of guava(Rs/qt)( channel 2)

\begin{tabular}{|c|c|c|c|c|}
\hline Particulars & VCA cost & Sales & Purchase & Net price \\
\hline Producer & - & 409 & - & 409 \\
\hline $\begin{array}{c}\text { Pre-harvest } \\
\text { Contractor }\end{array}$ & 283.42 & 735 & 409 & 42.68 \\
\hline Wholesaler & 140.40 & 1080 & 735 & 204.60 \\
\hline Retailer & 117.85 & 1395 & 1080 & 197.15 \\
\hline
\end{tabular}

The table 4 indicates the problems faced by guava growers. The highest percentage of growers faced the problem of guava wilt $(7.5 \%)$ followed by long chain of middlemen(3.5\%). Lack of government assistance is also one of the major reasons of low production and post harvest losses of guava. There is no proper provisions for farmers as www.ijeab.com how to increase their produce and also to store it properly, farmers are very weak financially and therefore the government should play a important role in providing them all facilities. If we see the district there are no proper cold storages and that's why a lot of the produce gets destroyed. Provisions should also be made for better transport facilities as it is also a major reason for post harvest loss. Most of the farmers are illiterate or very less educated therefore they do not have much market sense. The government should make good policies or give market guidance to s c h f a r mers. (Mishra et. al. 2013)

Table.4: Problems involved in the production and VCA of guava.

\begin{tabular}{|c|l|c|c|}
\hline $\begin{array}{c}\text { S. } \\
\text { NO }\end{array}$ & Problems & No. Of & Percentag \\
growers & ef \\
\hline 1. & Long chain of middlemen & 7 & 3.5 \\
\hline 2. & Lack of Government assistance & 5 & 2.5 \\
\hline 3. & Guava wilt & 15 & 7.5 \\
\hline 4. & No provision for proper grading \& & 3 & 1.5 \\
\hline 5. & No good processing unit in the & 3 & 1.5 \\
\hline 6. & No proper cold storages & 3 & 1.5 \\
\hline 7. & Lack of market intelligence & 3 & 1.5 \\
\hline 8. & In efficient transport facility & 4 & 2.0 \\
\hline 9. & Lack of proper infrastructural & 3 & 1.5 \\
\hline 10. & Lack of proper weights \&measures & 4 & 2.0 \\
\hline
\end{tabular}

\section{CONCLUSION}

The study was conducted to evaluate the production, marketing and Value Chain Analysis status of Guava in Allahabad district of Uttar Pradesh, India. From the study it could be concluded that the total yield of guava 57.88qtls in small size group, 102.4 in medium size group and 194.83 in large size group. Market surplus showed a tendency to increase with the increase in the size of holding. Sample average of marketable surplus was found to be $110.61 /$ ha of total production and it holds good for the surplus of the entire three size group. It was also observe that there were two main channels prevailing in the district i.e channel 1 composed of producer-wholesaler-retailer- consumer and channel 2 composed of producer-contractor- wholesalerretailer-consumer. According to the study channel 1 was more advantageous for the producer or farmer as the number of intermediataries involved in it was less and the producer gets the right money for his produce. The $\mathrm{m}$ a in and most common problem faced by the producers is guava wilt, the plant start dying at the age of

Page $\mid 120$ 
three-four years. There are still no measures to control guava wilt and the growers are losing interest in guava growing and cutting down guava orchards to convert it to lemon and mango orchards. Very soon some measures must be taken to prevent guava from this problem otherwise the reputation of growing the best orchards in Uttar Pradesh will be affected badly.

\section{REFERENCES}

[1] Jozsef L., Csaba.B.I., Komaromi N. and Lehota $z(2009)$. Development of Tracebility in Hungranian fresh vegetable and food sector. $4^{\text {th }}$ Aspects and Vision of Applied Economics and Informatics. March 26-27. Debrecen Hungary.

[2] Unnevehr, L.J.(2000). Food safety issues and fresh food products export from LDCs. Agril. Econ.,23: 231-240

[3] Mishra, Atul Anand, Shukla RN, Manna Preksha, Yadav K. C., and Kumar Avanish. "Value Chain Analysis of Guava-A Case Study of Allahabad District (Uttar Pradesh, India)." International Journal of Scientific \& Engineering Research, Volume 4, Issue 12, pp. 650-658,ISSN 2229-5518

[4] Kalei S.N.(2008).Supply Chain Management in Food Industry. Ifai University Press.

[5] Spriggs, J.(1999).W hat is in the world going on in food safety. Paper presented at the Food Safety and International Competitiveness Conference, April. Alberta .

[6] Subha, M.V. (2004), Managing Value Chain Analysis . Ind. J. Mktg. 34 (1) : 14-15.

[7] Suneel Arora and Mukesh Vyas., (2006), "IT organized retail management". Ind. J. Mktg. 36 (1): 8-11.

[8] Susanta. K, Roy, ( 2001), “Integrated Post Production Management N Food ProcessingTheNational objective". Ind. Food Packers. 55 (2):76-84

[9] Talamini E., Pedrozo E.A., Silva A.L(2005). Value Chain Analysis and food safety: exploratory research into Brazil's pork export supply chain.Gest.Prod.12 (1):107-120.

[10] Timothy, J., Richards and Stephen, F.H., ( 2006), Rivalry in Price and Variety among Supermarket Retailers. American J. Agric. Econ., 88 (3): 710-726.

[11] Tom Fox and Bill Vorley. (2003), Final report of the "Race to the Top" project by International Institute for Environment and Development. 